\title{
Aplikasi Jenis Teh Kompos dan Takaran Biochar terhadap Pertumbuhan Serta Produksi Biomassa Rumput Gajah (Pennisetum purpureum)
}

Yesephus Jemianus Madjen ${ }^{\text {a }}$

${ }^{a}$ Fakultas Pertanian, Universitas Timor, Kefamenanu, TTU - NTT, Indonesia, email: jemianusmadjen@gmail.com

\section{Article Info}

Article history:

Received 2 April 2018

Received in revised form 23 April 2018

Accepted 26 April 2018

DOI:

https://doi.org/10.32938/ja.v3i2.327

Keywords:

Teh Kompos

Biochar

Rumput Gajah

\section{Abstrak}

Penelitian ini dilaksanakan di Kelurahan Sasi Kecamatan Kota Kefamenanu Kabupaten TTU yang terdiri dari 2 masa produksi yaitu pada 45 HST dan 90 HST. Tujuan dari penelitian ini adalah untuk mengetahui pengaruh konsentrasi jenis teh kompos dan takaran biochar terhadap pertumbuhan serta produksi biomassa rumput gajah (Pennisetum purpureum). Rancangan yang digunakan adalah Rancangan Acak Lengkap (Faktorial) dengan kombinasi perlakuan $4 \times 3$ dengan 3 ulangan. Faktor petama adalah teh kompos yang terdiri dari $\mathrm{T}_{0}=$ tanpa teh kompos. $\mathrm{T} 1=$ teh kompos berbahan dasar feses ayam, T2 $=$ teh kompos berbahan dasar feses kambing dan T3 = teh kompos berbahan dasar feses sapi dan faktor ke dua adalah D0 = tanpa biochar, D1 = biochar $250 \mathrm{~g}$, D2 = biochar $500 \mathrm{~g}$. Hasil penelitian in menunjukkan bahwa tanaman rumput Gajah yang mendapat perlakuan teh kompos berbahan dasar feses ayam dan Biochar $500 \mathrm{~g}$ menampilkan pertumbuhan tinggi tanaman yang terbaik serta berbeda signifikan dengan perlakuan lainnya baik pada umur tanaman 24, dan 46 HST sedangkan untuk pertumbuhan jumlah helai daun yang terbaik serta berbeda signifikan dengan perlakuan lainnya baik pada umur tanaman 24, 46, 68 dan 90 HST. pertumbuhan diameter batang yang terbaik terdapat pada perlakuan teh kompos berbahan dasa feses ayam. Untuk berat segar daun terjadi interaksi antara pemberian teh kompos berbahan dasar feses ayam dan dosis biochar $500 \mathrm{~g} / \mathrm{pot}$ pada berat segar daun pada pemangkasan 46 HST sedangkan berat kering daun, berat segar akar dan berat kering akar tidak terjadi interaksi antara pemberian jenis teh kompos dan biochar pada pengamatan bobot kering daun. Disimpulkan bahwa perlakuan aplikasi teh kompos berbahan dasar feses ayam dab biochar $500 \mathrm{~g} /$ pot mampu meningkatkan produktivitas tanaman (tinggi tanaman, jumlah helai daun, diameter batang, berat segar daun, berat kering daun) rumput gajah yang lebih baik karena dalam teh kompos berbahan dasar feses ayam mengandung unsur $\mathrm{N}$ sebesar $0,174 \%$, P sebesar $0,260 \%$ dan $\mathrm{K}$ sebesar $0,137 \%$, sedangkan biochar dari bahan dasar sekam padi mengandung unsur $\mathrm{N}$ sebesar $1,318 \%$, unsur $\mathrm{P}$ sebesar $0,418 \%$, dan unsur $\mathrm{K}$ sebesar 1,506\% memberikan hasil yang baik namun belum mampu memberikan dampak signifikan terhadap nilai parameter pertumbuhan dan produksi rumput gajah.

\section{Pendahulua}

Rumput Gajah (Pennisetum purpureum) merupakan salah satu jenis rumput potong yang memiliki keunggulan yaitu produksi yang tinggi, kualitas nutrisi yang cukup tinggi dan ketahanan pada kondisi lahan seperti di Nusa Tenggara Timur (NTT). Budidaya rumput Gajah dilahan kering belum secara maksimal dilakukan oleh masyarakat peternak. Beberapa kendala yang menghambat produksi hijauan didaerah lahan kering seperti, kondisi iklim dilahan kering yang memiliki ciri seperti intensitas cahaya dan suhu lingkungan yang tingg serta curah hujan dan kelembapan yang rendah. Kondisi tersebut menyebapkan tidak sedikit jenis tanaman mengalami cekaman akibatnya produksi tanaman menjadi rendah. Menuru Suyirman (2003), rumput gajah memiliki produksi hijauan segar berkisar 500 - 800 ton/ha/tahun jumlah 7 kali panen pertahun, selanjutnya Rukmana (2005), menyatakan kandungan nutrisi rumput gajah terdiri atas: bahan kering (BK) 19, 9\%, protein kasar (PK) 10, 2\%, lemak kasar (LK) 1, 6\%, serat kasar (SK) 34, 2\%, abu 11, 7\%, dan bahan ekstrak tanpa nitrogen (BETN) 42, 3\%.

Penerapan teknologi sederhana seperti teh kompos dan biochar merupakan bentuk aplikasi teknologi dalam bidang budidaya hijuan makanan ternak yang memanfaatkan sumber nutrisi tersedia dan mikroorganisme untuk peningkatan kesuburan tanah. Bahan dasar pembuatan teh kompos maupun biochar dapat memanfaatkan bahan yang tersedia di alam seperti fases ternak maupun limbah pertanian seperti sekam padi.

Teh kompos memiliki beberapa keuntungan dan merupakan produk pupuk alami yang ramah lingkungan, disamping sebagai pupuk alami teh kompos juga dapat berfungs sebagai pestisida alami, karena teh kompos mampu mengembalikan kesuburan tanah secara alami serta meningkatkan daya tahan tanaman terhadap hama dan penyakit. Di dalam teh kompos terdapat lebih dari 5.000.000 mikroorganisme yang bermanfaat untuk meningkatkan kesuburan tanah, menyehatkan tanaman, mengurangi kerusakan akibat serangan patogen tular tanah dan patogen penyebap penyakit pada daun tanaman (Litterick $d k k . ., 2004$ ). Sedangkan biochar merupakan salah satu bentuk aplikasi teknologi yang memanfaatkan bahan hasil limbah yang tersedia di alam untuk dimanfaatkan sebagai media pembenah tanah, dalam usaha meningkatkan nilai produksi tanaman. Lehman \& Joseph (2009), mengatakan bahwa biochar merupakan bahan yang memiliki kandungan karbon tinggi yang berasal dari biomassa kayu atau sisa hasil pengolahan tanaman yang dibakar di suatu wadah dengan sedikit atau tanpa udara.

Pemberian biochar ke dalam tanah dapat meningkatkan kesubururan tanah karena Biochar mampu mengikat karbon dan menyediakan habitat yang baik bagi kehidupan mikroorganisme tanah. Dengan penerapan paket teknologi berupa pemberian teh kompo dan biochar diharapkan mampu menyediakan nutrisi dan mikroorganisme pada tanah sehingga tanaman mampu memanfaatkan semua potensi yang tersedia pada tanah untuk pertumbuhan maupun produksi.

\section{Metode}

Peralatan yang digunakan dalam penelitian ini terdiri dari peralatan utama seperti pot kapasitas $5 \mathrm{~kg}$ tanah sebanyak 36 buah, rak tanaman sebanyak 3 buah dimana tiap rak berukuran $2 \times 1 \mathrm{~m}$, timbangan, oven, peralatan bercocok tanam dan bahan yang digunakan adalah stek rumput gajah (Pennisetum purpureum) 72 stek, Biochar dari bahan dasar sekam padi sebanyak $20 \mathrm{~kg}$ dan bahan dasar pembuatan teh kompos dari feses sapi, feses kambing, feses ayam masing - masing sebanyak $25 \mathrm{~kg}$, tanah jenis incepticol yang telah diayak sebanyak $180 \mathrm{~kg}$.

Penelitian menggunakan model experimen dengan Rancangan Acak Lengkap (RAL) pola faktorial $4 \times 3 \times 3$. Adapun perlakuan yang diuji terdiri dari:

Faktor pertama jenis teh kompos (T), terdiri dari empat taraf yakni:

T0 : Tanpa Teh kompos (control);

T1 : Jenis Teh kompos dari feses ayam;

T2 : Jenis Teh kompos dari feses kambing;

T3 : Jenis Teh kompos dari feses sapi.

Faktor kedua pemberian Biochar (D), terdiri dari tiga taraf yakni:

D0 : Tanpa Biochar (Kontrol)

D1 : Biochar 250 gram/pot;

D2 : Biochar 500 gram/pot.

Pembuatan biochar dimulai dengan pembakaran sekam padi dalam alat pembakaran yang dirancang khusus untuk membakar biochar sekam padi. Pada bagian tengah ala pembakaran ditempatkan corong berbentuk selinder yang dibuat dengan melubangi dinding corong dengan jarak $2 \mathrm{~cm}$, selanjutnya sekam padi diletakan antara dinding alat pembaka dan corong. Setelah itu pada bagian tengah corong dinyalakan api dengan menggunakan kayu yang telah kering, dengan demikian proses pembakaran dimulai. Pembalikan pada sekam padi yang sedang dibakar dimana sekam padi yang belum terbakar pada bagian bawah di balik keatas sehingga proses pembakaran dapat merata. Proses pembakaran berlangsung selama \pm 5 jam. Setelah proses pembakaran berlangsung selanjutnya sekam yang telah dibakar disiram dengan menggunakan air. Adapun penyiraman dilakukan agar sekam tidak berubah bentuk menjadi abu oleh karena itu proses pembakaran ini di sebut pembakara tidak sempurna karena tidak langsung menggunakan api untuk membuat biochar. Lalu dibiarkan beberapa saat sampai suhu pada biochar menjadi lebih dingin. Selanjutnya sekam yang telah dibakar dikeringkan dengan melakukan penjemuran dibawah matahari selama 3 hari sampai kering. Pada tahapan terakhir biochar yang telah dikeringkan ditumbuk dengan menggunakan lesung dan disaring sampai ukuran partikel seragam.

Bahan-bahan yang digunakan untuk pembuatan kompos adalah campuran sebanyak $50 \mathrm{~kg}$ untuk setiap jenis kompos, feses ayam $25 \mathrm{~kg}$, feses kambing $25 \mathrm{~kg}$, feses sapi $25 \mathrm{~kg}$, dedak padi $8 \mathrm{~kg}$ untuk tiap jenis kompos, EM4 $100 \mathrm{ml}$ untuk tiap jenis kompos, gula aren 100 $\mathrm{ml}$ untuk tiap jenis kompos, dan air 10 liter untuk tiap jenis kompos. Proses pembuatan kompos adalah sebagai berikut: tiap jenis feses (ayam, kambing dan sapi) dan hijauan yang telah disiapkan dicampur secara merata dengan dedak padi kemudian disirami sambil diaduk secara merata dengan air yang didalamnya telah dilarutkan EM4 dan gula air. Adonan kemudian dibuat tumpukan setebal $2-3 \mathrm{~cm}$ untuk setiap jenis kompos (kompos ayam, kompos kambing dan kompos sapi), ditutup dengan karung atau penutup lainnya, dibalik setiap hari, suhu tumpukan diamati hingga matang. Untuk mendapatkan masing-masing teh kompos air leding disiapkan dalam ember sebanyak 3 liter, untuk tiap jenis kompos selanjutnya timbang tiap jenis kompos sebanyak $1 \mathrm{~kg}$ yang telah dibungkus dengan kain kas dimasukan ke dalam ember tersebut, dan ditambahkan larutan gula air $50 \mathrm{ml}$. Campuran tersebut diaduk selama 24 jam menggunakan aerator. Setelah 24 jam, teh kompos yang harum baunya disaring menggunakan saringan air dan siap untuk diaplikasikan.

Variabel yang dilihat adalah tinggi tanaman, jumlah helai daun, berat segar dan berat kering daun, berat segar dan berat kering akar rumput gajah. Pengambilan data dilakukan 2 kali dalam satu masa produksi, sedangkan berat segar daun, berat kering daun, berat segar akar dan berat kering akar dilakukan pada akhir masa produksi I (45 HST) dan produksi II (90 HST). Data pengamatan dianalisis menggunakan sidik ragam (Anova) sesuai Rancangan Acak lengkap (RAL) pola faktorial. Jika perlakuan berbeda signifikan diuji lanjut dengan menggunakan uji Duncan. Analisis data menggunakan program SAS 9.

\section{Hasil dan Pembahasan}

\subsection{Tinggi Tanaman Rumput Gajah}

Tunas rumput gajah terus bertambah tinggi bersamaan dengan pertambahan waktu, hasil sidik ragam (Anova) menunjukan tidak terjadi interaksi antara pemberian jenis te kompos dan biochar terhadap stek rumput gajah pada pengamatan tingoi tanaman umur 24 s/d 90 HST. Pemberian teh kompos berbahan dasar feses ayam, nyata memberikan pertumbuhan tertinggi tanaman pada pengamatan 24, 46 dan 90 HST. Pemberian biochar tidak memberikan pengaruh yang nyata namun pada level pemberian $500 \mathrm{~g} / \mathrm{pot}$ cenderung meningkatkan pertumbuhan tinggi tanaman.

Hasil penelitian ini menunjukkan bahwa tanaman rumput gajah yang mendapa perlakuan teh kompos berbahan dasar feses ayam dan biochar $500 \mathrm{~g}$ menampilkan pertumbuhan tinggi tanaman yang terbaik serta berbeda signifikan dengan perlakuan lainnya baik pada umur tanaman 24, dan 46 HST. Hal ini mengindikasikan bahwa antar perlakuan aplikasi teh kompos berbahan dasar feses ayam dan pemberian level biochar 500g baik secara parsial maupun bersama-sama berkontribusi dalam menghasilan sedimen yang kaya akan unsur bahan organik yang secara biologis telah difasilitasi oleh mikroorganisme. Pemberian teh kompos berbahan dasar feses ayam meningkatkan ketersediaan $\mathrm{N}$ sebesa $0,174 \%$ sehingga mampu mencukupi kebutuhan tanaman. Nitrogen diketahui merupakan salah satu unsur yang berperan penting dalam proses pembelahan dan pembesaran sel yan merupakan dasar dari pertumbuhan tanaman, seperti pertambahan tinggi tanaman. Hasil pengamatan tinggi tanaman ditampilkan pada Tabel 1

Dalam teh kompos berbahan dasar feses ayam juga terdapat mikroorganisme antagonis yang membunuh pathogen sehingga kesehatan tanaman lebih terjaga. Sedangkan biochar sendiri dapat berfungsi sebagai pembenah tanah, meningkatkan pertumbuhan tanaman dengan menambahkan sejumlah nutrisi yang berguna sehingga meningkatkan sifa kimia, fisika dan biologi tanah. Dengan demikian penggunaan keduanya menghasilka 
sistem drainase yang baik, memiliki daya intermolekul yang dapat mempengaruhi kecepatan perkecambahan, dan pembelahan sel. Dalam biochar terdapat kandungan N sebesar 1,318\% sehingga mampu memacu pertumbuhan tinggi tanaman rumput Gajah. Kandungan unsurunsur hara itu ada yang dapat mempercepat pertumbuhan tanaman (Glasser $d k k$., 2002; Lehmann $d k k$., 2003; Lehmann \& Rondon, 2006; Steiner $d k k, 2007)$.

Tabel 1. Tinggi Tanaman Rumput Gajah yang Memperoleh Jenis Teh Kompos dan Level Biochar yang Berbeda.

\begin{tabular}{|c|c|c|c|c|c|}
\hline \multirow{2}{*}{$\begin{array}{c}\text { Waktu } \\
\text { Pengamatan }\end{array}$} & \multirow{2}{*}{$\begin{array}{c}\text { Jenis } \\
\text { Teh Kompos }\end{array}$} & \multicolumn{3}{|c|}{ Dosis Biochar $(\mathrm{g})$} & \multirow{2}{*}{ Rerata } \\
\hline & & Kontrol & 250 & 500 & \\
\hline \multirow{5}{*}{$24 \mathrm{HST}$} & Kontrol) & 6.26 & 6.29 & 5.79 & $6.12^{\mathrm{ab}}$ \\
\hline & Feses Ayam) & 6.60 & 6.03 & 7.39 & $6.68^{a}$ \\
\hline & Feses Kambing) & 4.99 & 6.05 & 6.76 & $5.93^{\mathrm{ab}}$ \\
\hline & Feses Sapi) & 4.81 & 4.84 & 5.96 & $5.20^{\mathrm{b}}$ \\
\hline & Rerata & $5.67^{\mathrm{a}}$ & $5.80^{\mathrm{a}}$ & $6.48^{\mathrm{a}}$ & $(-)$ \\
\hline \multirow{5}{*}{46 HST } & Kontrol & 7.05 & 6.54 & 5.77 & $6.45^{\mathrm{ab}}$ \\
\hline & Feses Ayam & 7.19 & 7.34 & 7.41 & $7.31^{\mathrm{a}}$ \\
\hline & Feses Kambing & 5.10 & 6.71 & 7.11 & $6.31^{\mathrm{ab}}$ \\
\hline & Feses Sapi & 5.76 & 6.02 & 6.53 & $6.10^{\mathrm{b}}$ \\
\hline & Rerata & $6.27^{\mathrm{a}}$ & $6.65^{\mathrm{a}}$ & $6.71^{\mathrm{a}}$ & $(-)$ \\
\hline \multirow{5}{*}{$68 \mathrm{HST}$} & Kontrol & 7.79 & 8.21 & 9.16 & $8.39^{\mathrm{a}}$ \\
\hline & Feses Ayam & 8.79 & 9.14 & 9.48 & $9.14^{\mathrm{a}}$ \\
\hline & Feses Kambing & 7.86 & 8.10 & 7.92 & $7.96^{\mathrm{a}}$ \\
\hline & Feses Sapi & 8.55 & 8.63 & 8.58 & $8.59^{\mathrm{a}}$ \\
\hline & Rerata & $8.25^{\mathrm{a}}$ & $8.61^{\mathrm{a}}$ & $8.70^{\mathrm{a}}$ & $(-)$ \\
\hline \multirow{5}{*}{$90 \mathrm{HST}$} & Kontrol & 9.21 & 10.03 & 10.68 & $9.98^{\mathrm{a}}$ \\
\hline & Feses Ayam & 10.60 & 10.90 & 11.85 & $11.12^{\mathrm{a}}$ \\
\hline & Feses Kambing & 9.79 & 10.11 & 10.36 & $10.09^{\mathrm{a}}$ \\
\hline & Feses Sapi & 11.25 & 9.68 & 10.08 & $10.34^{\mathrm{a}}$ \\
\hline & Rerata & $10.21^{\mathrm{a}}$ & $10.42^{\mathrm{a}}$ & $10.51^{\mathrm{a}}$ & $(-)$ \\
\hline
\end{tabular}

Pada periode pertumbuhan ke dua (pasca panen pertama) menunjukkan bahwa tanaman rumput gajah yang mendapat perlakuan teh kompos berbahan dasar feses ayam dan biochar $500 \mathrm{~g}$ menampilkan pertumbuhan tinggi tanaman yang terbaik namun tidak signifikan dengan perlakuan lainnya baik pada umur tanaman 68 HST maupun umur 90 HST. Hal ini dikarenakan pada periode pertumbuhan fase kedua semua unsur hara yang terdapat dalam media tumbuh tanaman lebih diarahkan untuk pembentukan daun dan hanya sedikit yang digunakan untuk pertambahan tinggi tanaman. Hasil penelitian Ryoo (2014) menunjukkan bahwa penggunaan aplikasi teh kompos pada tanaman ginseng di Korea dapa meningkatkan jumlah daun dan kadar klorofil, menekan defoliasi daun serta meningkatkan panjang dan berat akar.

\subsection{Jumlah Helai Daun Rumput Gajah}

Jumlah helai daun meningkat seiring bertambahnya umur tunas, hasil sidik ragam menunjukkan terjadi interaksi antara pemberian jenis teh kompos berbahan dasar feses ayam dan pemberian biochar $500 \mathrm{~g} /$ pot pada pengamatan 90 HST. Pemberian jenis teh kompos berbahan dasar feses ayam dan biochar $500 \mathrm{~g} /$ pot pada pengamatan 46 dan 68 HST, nyata meningkatkan jumlah daun terbanyak dibanding pemberian jenis teh kompos dan dosis biochar lainnya. Hasil pengamatan jumlah helai daun rumput gajah di tampilkan pada Tabel 2 .

Tabel 2. Jumlah Helai Daun Rumput Gajah yang Memperoleh Jenis Teh Kompos dan Level Biochar yang Berbeda.

\begin{tabular}{clcccc}
\hline Waktu & \multicolumn{1}{c}{ Jenis } & \multicolumn{3}{c}{ Dosis Biochar $(\mathrm{g})$} & \multirow{2}{*}{ Rerata } \\
\cline { 2 - 5 } Pengamatan & Teh Kompos & Kontrol & 250 & 500 & \\
\hline \multirow{5}{*}{24 HST } & Kontrol & 3.92 & 4.21 & 4.10 & $4.07^{\mathrm{a}}$ \\
& Feses Ayam & 4.08 & 4.44 & 4.57 & $4.37^{\mathrm{a}}$ \\
& Feses Kambing & 3.79 & 4.26 & 4.26 & $4.10^{\mathrm{a}}$ \\
& Feses Sapi & 3.08 & 3.33 & 3.83 & $3.42^{\mathrm{b}}$ \\
\cline { 2 - 5 } & Rerata & $3.72^{\mathrm{a}}$ & $4.06^{\mathrm{a}}$ & $4.19^{\mathrm{a}}$ & $(-)$ \\
\hline \multirow{5}{*}{$46 \mathrm{HST}$} & Kontrol & 4.33 & 4.54 & 4.76 & $4.55^{\mathrm{b}}$ \\
& Feses Ayam & 5.33 & 5.04 & 5.75 & $5.38^{\mathrm{a}}$ \\
& Feses Kambing & 4.35 & 4.18 & 4.99 & $4.51^{\mathrm{b}}$ \\
& Feses Sapi & 4.31 & 4.68 & 4.67 & $4.55^{\mathrm{b}}$ \\
\cline { 2 - 5 } & Rerata & $4.58^{\mathrm{a}}$ & $4.79^{\mathrm{a}}$ & $4.87^{\mathrm{a}}$ & $(-)$ \\
\hline \multirow{5}{*}{$68 \mathrm{HST}$} & Kontrol & 5.30 & 6.41 & 6.63 & $6.11^{\mathrm{bc}}$ \\
& Feses Ayam & 6.62 & 7.50 & 7.55 & $7.22^{\mathrm{a}}$ \\
& Feses Kambing & 6.00 & 4.79 & 5.60 & $5.46^{\mathrm{c}}$ \\
& Feses Sapi & 6.68 & 6.44 & 6.46 & $6.53^{\mathrm{b}}$ \\
\cline { 2 - 5 } & Rerata & $6.15^{\mathrm{a}}$ & $6.29^{\mathrm{a}}$ & $6.56^{\mathrm{a}}$ & $(-)$ \\
\hline \multirow{5}{*}{$90 \mathrm{HST}$} & Kontrol & 6.52 & 7.63 & 8.14 & $7.43^{\mathrm{b}}$ \\
& Feses Ayam & 8.00 & 8.37 & 9.00 & $8.46^{\mathrm{a}}$ \\
& Feses Kambing & 7.52 & 5.83 & 6.82 & $6.72^{\mathrm{b}}$ \\
& Feses Sapi & 6.40 & 7.96 & 7.70 & $7.36^{\mathrm{b}}$ \\
\cline { 2 - 5 } & Rerata & $7.11^{\mathrm{b}}$ & $7.45^{\mathrm{ab}}$ & $7.92^{\mathrm{a}}$ & $(+)$ \\
\hline Keterangan: & Angka pada kolom dan baris diikuti huruf sama, menunjukkan tidak berbeda pada tingkat
\end{tabular}

Keterangan: Angka pada kolom dan baris diikuti huruf sama, menunjukkan tidak berbeda pada tingk

Hasil penelitian ini menunjukkan bahwa tanaman rumput gajah yang mendapa perlakuan teh kompos berbahan dasar feses ayam menampilkan pertumbuhan jumlah helai daun yang terbaik serta berbeda signifikan dengan perlakuan lainnya baik pada umur tanaman 24, 46, 68 dan 90 HST. Hal ini dikarenakan pada tanaman rumput gajah yang mendapat aplikasi teh kompos unsur hara dan mikroba dari kompos yang terdeposit dalam tanah disamping menyediakan oksigen yang memadai bagi mikroorganisme juga merangsang pertumbuhan bakteri pengurai sehingga struktur tanah menjadi lebih baik karena teh kompos memiliki unsur $\mathrm{N}$ sebesar $0,174 \%$. Manfaat teh kompos menurut Nasir (2007) adalah memperbaiki sistem jaringan sel-sel rusak, merangsang pertumbuhan sel-sel baru pada tumbuhan dan memperkuat daya tahan pada tanaman.

Hasil penelitian ini juga menunjukkan bahwa tanaman rumput gajah yang mendapat perlakuan biochar hingga $500 \mathrm{~g} /$ pot menampilkan pertumbuhan jumlah helai daun yan terbaik tetapi tidak signifikan dengan perlakuan lainnya pada umur tanaman 24, 46, dan 68 HST dan berbeda singnifikan pada umur 90 HST. Biochar mengandung unsur N sebesar
$1,318 \%$ sehingga mampu meningkatkan jumlah helai daun tanaman rumput gajah. Dua ha utama yang menjadi potensi biochar di bidang pertanian adalah afinitasnya yang tinggi terhadap unsur hara dan persistensinya. biochar lebih persisten dalam tanah, sehingga semua manfaat yang berhubungan dengan retensi hara dan kesuburan tanah dapat berjalan lebih lama dibanding kandungan bahan organik lain yang biasa diberikan (Gani, 2010)

\subsection{Diameter Batang Rumput Gajah}

Diameter batang tanaman rumput gajah meningkat seiring bertambahnya umur tanaman. Hasil sidik ragam menunjukkan tidak terjadi interaksi antara pemberian jenis teh kompos dan biochar terhadap pertumbuhan rumput gajah pada pengamatan diameter batang. Pemberian jenis teh kompos berbahan dasar feses ayam, nyata memberikan pengaruh pada pertambahan diameter batang waktu pengamatan 24 HST, sedangkan pada pengamatan 46 , 68 dan 90 HST memberi pengaruh yang tidak nyata. Pemberian biochar tidak menunjukan beda nyata namun pada dosis pemberian $500 \mathrm{~g} /$ pot cenderung meningkatkan diameter batang. Hasil penelitian ini menunjukkan bahwa tanaman rumput gajah yang mendapat perlakuan teh kompos berbahan dasar feses ayam menampilkan pertumbuhan diameter batang yang terbaik. Hal ini dikarenakan pada tanaman rumput gajah yang mendapat aplikasi teh kompos berbahan dasar feses ayam yang mengandung unsur $\mathrm{N}$ sebesar $0,174 \%$ dan mikroba dari kompos dalam tanah disamping menyediakan oksigen yang memadai bagi mikroorganisme juga merangsang pertumbuhan bakteri pengurai sehingga struktur tanah menjadi lebih baik. Diameter tanaman rumput gajah bertambah panjang dan besar karena adanya penambahan jumlah sel sebagai hasil pembelahan mitosis.

Di dalam tanah, biochar menyediakan habitat yang baik bagi mikroba tanah misalnya bakteri yang membantu dalam perombakan unsur hara agar unsur hara tersebut dapat diserap oleh tanaman dan menstimulasi simbiosis fiksasi Nitrogen. Dalam jangka panjang biochar tidak mengganggu keseimbangan Karbon-Nitrogen, bahkan mampu menahan dan menjadikan air dan nutrisi lebih tersedia bagi tanaman. Meningkatnya jumlah organisme tanah terutama organisme penambat $\mathrm{N}$ mampu menunjang pertumbuhan dan hasil tanaman (Gani, 2010). Hasil pengamatan diameter batang tanaman ditunjukan pada Tabel 3.

Tabel 3. Diameter Batang Tanaman Rumput Gajah yang Memperoleh Jenis Teh Kompos dan Level Biochar yang Berbeda.

\begin{tabular}{|c|c|c|c|c|c|}
\hline \multirow{2}{*}{$\begin{array}{c}\text { Waktu } \\
\text { Pengamatan }\end{array}$} & \multirow{2}{*}{$\begin{array}{c}\text { Jenis } \\
\text { Teh Kompos }\end{array}$} & \multicolumn{3}{|c|}{ Dosis Biochar (g) } & \multirow{2}{*}{ Rerata } \\
\hline & & Kontrol & 250 & 500 & \\
\hline \multirow{5}{*}{$24 \mathrm{HST}$} & Kontrol & 0.56 & 0.69 & 0.75 & $0.67^{\mathrm{b}}$ \\
\hline & Feses Ayam & 0.71 & 0.78 & 0.79 & $0.76^{\mathrm{a}}$ \\
\hline & Feses Kambing & 0.71 & 0.74 & 0.73 & $0.73^{\mathrm{ab}}$ \\
\hline & Feses Sapi & 0.61 & 0.65 & 0.72 & $0.66^{\mathrm{b}}$ \\
\hline & Rerata & $0.65^{\mathrm{a}}$ & $0.71^{\mathrm{a}}$ & $0.75^{\mathrm{a}}$ & $(-)$ \\
\hline \multirow{5}{*}{46 HST } & Kontrol & 0.60 & 0.64 & 0.70 & $0.64^{\mathrm{a}}$ \\
\hline & Feses Ayam & 0.70 & 0,62 & 0.76 & $0.70^{\mathrm{a}}$ \\
\hline & Feses Kambing & 0.52 & 0.64 & 0.72 & $0.63^{\mathrm{a}}$ \\
\hline & Feses Sapi & 0.62 & 0.63 & 0.56 & $0.61^{\mathrm{a}}$ \\
\hline & Rerata & $0.61^{\mathrm{a}}$ & $0.65^{\mathrm{a}}$ & $0.67^{\mathrm{a}}$ & $(-)$ \\
\hline \multirow{5}{*}{68 HST } & Kontrol & 0.80 & 0.90 & 0.94 & $0.88^{\mathrm{a}}$ \\
\hline & Feses Ayam & 0.96 & 0.88 & 1.03 & $0.96^{\mathrm{a}}$ \\
\hline & Feses Kambing & 0.87 & 0.91 & 0.95 & $0.91^{\mathrm{a}}$ \\
\hline & Feses Sapi & 0.83 & 0.92 & 0.91 & $0.89^{\mathrm{a}}$ \\
\hline & Rerata & $0.86^{\mathrm{a}}$ & $0.90^{\mathrm{a}}$ & $0.96^{\mathrm{a}}$ & $(-)$ \\
\hline \multirow{5}{*}{$90 \mathrm{HST}$} & Kontrol & 1.02 & 1.11 & 1.21 & $1.11^{\mathrm{a}}$ \\
\hline & Feses Ayam & 1.20 & 1.15 & 1.27 & $1.20^{\mathrm{a}}$ \\
\hline & Feses Kambing & 1.12 & 1.16 & 1.22 & $1.17^{\mathrm{a}}$ \\
\hline & Feses Sapi & 1.09 & 1.19 & 0.94 & $1.07^{\mathrm{a}}$ \\
\hline & Rerata & $1.11^{\mathrm{a}}$ & $1.15^{\mathrm{a}}$ & $1.16^{\mathrm{a}}$ & $(-)$ \\
\hline
\end{tabular}
nyata (a) $5 \%$, uji DMRT. (-): Tidak terjadi interaksi antar faktor

\subsection{Berat Segar Daun Rumput Gajah}

Hasil sidik ragam menunjukkan terjadi interaksi antara pemberian teh kompos berbahan dasar feses ayam dan dosis biochar $500 \mathrm{~g} / \mathrm{pot}$ pada berat segar daun pada pemangkasan 46 HST. Pemberian teh kompos berbahan dasar feses ayam memberikan pengaruh nyata pula pada pemangkasan $90 \mathrm{HST}$, sedangkan pemberian biochar tidak menunjukan beda nyata namun pada dosis pemberian $500 \mathrm{~g} /$ pot cenderung meningkatkan berat segar daun.

Hasil penelitian menunjukkan bahwa pemberian jenis teh kompos berbahan dasar feses ayam dan dosis biochar $500 \mathrm{~g} /$ pot meningkatkan pertumbuhan dan produksi rumput gajah yang dapat diekspresikan dalam bentuk jumlah daun terbanyak $(9,00 \mathrm{~g})$ (pertumbuhan) dan berat segar daun $(2,78 \mathrm{~g})$ paling berat (hasil/produksi). Hal ini juga dapat dilihat pada hampir semua variabel pengamatan yang menunjukkan bahwa jenis teh kompos berbahan dasar feses ayam dengan kandungan unsur $\mathrm{N}$ sebesar $0,174 \%$ secara nyata memberikan pengaruhnya. Dosis biochar $500 \mathrm{~g} /$ pot juga mampu meningkatkan pertumbuhan dan produksi rumput gajah pada setiap variabel pengamatan. Hasil penelitian juga menunjukkan bahwa pemberian biochar hingga 500 gram/pot memberikan berat segar terberat yaitu 1,97 gram (46 HST) dan 5,88 gram (90 HST) karena biochar sendiri mengandung unsur N sebesa $1,318 \%$. Pemberian unsur $\mathrm{N}$ berfungsi untuk merangsang pertumbuhan daun, menghijaukan daun, serta mempertinggi kandungan protein (Lehmann $d k k$., 2009). Hasil pengamatan berat segar daun rumput gajah ditampilkan pada Tabel 4.

Tabel 4. Berat Segar Daun Rumput Gajah yang Memperoleh Jenis Teh Kompos dan Level Biochar yang Berbed.

\begin{tabular}{clcccc}
\hline Waktu & \multicolumn{1}{c}{ Jenis } & \multicolumn{3}{c}{ Dosis Biochar $(\mathrm{g})$} & \multirow{2}{*}{ Rerata } \\
\cline { 3 - 5 } Pengamatan & Teh Kompos & Kontrol & 250 & 500 & \\
\hline \multirow{4}{*}{$46 \mathrm{HST}$} & Kontrol & 1.93 & 1.60 & 1.84 & $1.79^{\mathrm{a}}$ \\
& Feses Ayam & 1.59 & 1.87 & 2.78 & $2.08^{\mathrm{a}}$ \\
& Feses Kambing & 2.07 & 2.66 & 1.22 & $1.98^{\mathrm{a}}$ \\
& Feses Sapi & 0.85 & 1.35 & 2.03 & $1.41^{\mathrm{a}}$ \\
\cline { 2 - 5 } & Rerata & $1.61^{\mathrm{a}}$ & $1.87^{\mathrm{a}}$ & $1.97^{\mathrm{a}}$ & $(+)$ \\
\hline \multirow{5}{*}{$90 \mathrm{HST}$} & Kontrol & 3.36 & 2.80 & 2.81 & $2.99^{\mathrm{ab}}$ \\
& Feses Ayam & 8.82 & 8.63 & 8.93 & $8.79^{\mathrm{a}}$ \\
& Feses Kambing & 7.42 & 9.31 & 8.12 & $8.28^{\mathrm{ab}}$ \\
& Feses Sapi & 4.81 & 5.81 & 3.65 & $4.76^{\mathrm{b}}$ \\
\cline { 2 - 5 } & Rerata & $6.10^{\mathrm{a}}$ & $6.64^{\mathrm{a}}$ & $5.88^{\mathrm{a}}$ & $(-)$ \\
\hline Keterangan: & Angka pada kolom dan baris diikuti huruf sama, menunjukkan tidak berbeda pada tingkat
\end{tabular}

nyata (a) $5 \%$, uji DMRT. (-): Tidak terjadi interaksi antar faktor. (+) Terjadi interaksi antar faktor. 


\subsection{Berat Kering Daun Rumput Gajah}

Hasil sidik ragam menunjukkan tidak terjadi interaksi antara pemberian jenis teh kompos dan biochar pada pengamatan bobot kering daun. Pemberian teh kompos berbahan dasar feses ayam secara nyata meningkatkan berat kering daun paling tinggi dibanding jenis teh kompos lainnya pada pemangkasan 46 dan 90 HST. Pemberian dosis biochar $500 \mathrm{~g} / \mathrm{po}$ memberikan pengaruh pada pemangkasan 46 HST sedangkan pada pemangkasan 90 HST tidak menunjukan beda nyata namun rata-rata level pemberian yang berbeda cendrung meningkatkan berat kering daun. Hasil pengamatan berat kering daun rumput gajah di tampilkan pada Tabel 5 .

Tabel 5. Berat Kering Daun Rumput Gajah yang Memperoleh Jenis Teh Kompos dan level Biochar yang Berbeda.

\begin{tabular}{clcccc}
\hline \multirow{2}{*}{$\begin{array}{c}\text { Waktu } \\
\text { Pemangkasan }\end{array}$} & \multirow{2}{*}{ Jenis Teh Kompos } & \multicolumn{3}{c}{ Dosis Biochar $(\mathrm{g})$} & \multirow{2}{*}{ Rerata } \\
\cline { 3 - 5 } & & Kontrol & 250 & 500 & \\
\hline \multirow{4}{*}{$46 \mathrm{HST}$} & Kontrol & 0.47 & 0.41 & 0.46 & $0.45^{\mathrm{ab}}$ \\
& Feses Ayam & 0.42 & 0.44 & 0.66 & $0.51^{\mathrm{a}}$ \\
& Feses Kambing & 0.32 & 0.49 & 0.64 & $0.48^{\mathrm{ab}}$ \\
& Feses Sapi & 0.22 & 0.34 & 0.47 & $0.34^{\mathrm{b}}$ \\
\cline { 2 - 5 } & Rerata & $0.36^{\mathrm{b}}$ & $0.42^{\mathrm{b}}$ & $0.56^{\mathrm{a}}$ & $(-)$ \\
\hline \multirow{5}{*}{$90 \mathrm{HST}$} & Kontrol & 1.02 & 0.97 & 0.93 & $0.98^{\mathrm{c}}$ \\
& Feses Ayam & 2.33 & 2.51 & 2.51 & $2.45^{\mathrm{a}}$ \\
& Feses Kambing & 2.05 & 2.42 & 2.34 & $2.27^{\mathrm{a}}$ \\
& Feses Sapi & 1.40 & 1.72 & 1.19 & $1.43^{\mathrm{b}}$ \\
\cline { 2 - 4 } Keterangan: & Angka pada kolom dan baris diikuti huruf sama, menunjukkan tidak berbeda pada tingkat \\
& nyata $(\alpha)$ 5\%, uji DMRT. (-): Tidak terjadi interaksi antar faktor. & &
\end{tabular}

Pada Tabel 5. mengindikasikan bahwa pemberian teh kompos feses ayam dengan kandungan unsur $\mathrm{N}$ sebesar $0,174 \%$ dan biochar dengan dosis 500 gram/pot dengan kandungan unsur $\mathrm{N}$ sebesar $1,318 \%$ telah mampu meningkatkan berat kering daun tanaman rumput gajah. Jika unsur hara yang dibutuhkan tanaman tersedia dalam jumlah yang cukup, maka hasil metabolisme seperti sintesis biomolekul akan meningkat (Lehmann, 2007). Hasi yang berbeda terhadap perhitungan jumlah biomassa berupa berat kering daun pada penelitian ini diduga dipengaruhi oleh laju produksi biomassa yang berbeda pada setiap rumpun rumput gajah. Dimana menurut Niinemets (2007), laju produksi biomassa (bahan kering) tanaman tergantung laju akumulasi biomassa harian dikurangi kehilangan biomassa oleh proses fisiologi seperti respirasi. Selain itu, akumulasi biomassa suatu tanaman dipengaruhi oleh umur, dan ketersediaan hara tanah.

\subsection{Berat Segar Akar Rumput Gajah}

Hasil sidik ragam menunjukkan tidak terjadi interaksi antara jenis teh kompos dan dosis biochar pada pengamatan berat segar akar. Berat segar akar terberat ditunjukkan oleh perlakuan teh kompos berbahan feses ayam dan perlakuan kontrol. Hasil pengamatan berat segar akar rumput gajah di tampilkan pada Tabel 6 .

Tabel 6. Berat Segar Akar Rumput Gajah yang Memperoleh Jenis Teh Kompos dan Level Biochar yang Berbeda.

\begin{tabular}{lcccc}
\hline \multirow{2}{*}{ Jenis Teh Kompos } & \multicolumn{3}{c}{ Dosis Biochar $(\mathrm{g})$} & \multirow{2}{*}{ Rerata } \\
\cline { 2 - 4 } & Kontrol & 250 & 500 & \\
\hline Kontrol & 35,32 & 29,71 & 14,87 & $26,63^{\mathrm{c}}$ \\
Feses Ayam & 72,96 & 78,39 & 72,93 & $74,76^{\mathrm{a}}$ \\
Feses Kambing & 71,26 & 59,48 & 48,37 & $59,70^{\mathrm{b}}$ \\
Feses Sapi & 29,10 & 25,86 & 48,08 & $34,35^{\mathrm{c}}$ \\
\hline \multicolumn{1}{c}{ Rerata } & $52,16^{\mathrm{a}}$ & $48,36^{\mathrm{a}}$ & $46,06^{\mathrm{a}}$ & $(-)$ \\
\hline
\end{tabular}

Keterangan: Angka pada kolom dan baris diikuti huruf sama, menunjukkan tidak berbeda pada tingkat nyata ( $\alpha$ ) $5 \%$, uji DMRT. (-): Tidak terjadi interaksi antar faktor

Hasil penelitian menunjukkan tanaman yang mendapat perlakuan teh kompos berbahan feses ayam dengan kandungan unsur $\mathrm{N}$ sebesar $0,174 \%$ dan kontrol memberikan berat segar akar terberat yaitu (74,76 dan 52,16 g) dan berbeda nyata jika dibandingkan dengan berat segar akar yang pada perlakuan lainnya. Akar tanaman berfungsi sebagai organ yang menyerap hara dan air, walaupun tanaman dapat memperoleh hara dan air dari daun, tetapi dibandingkan dengan jumlah yang diperoleh dari penyerapan akar, penyerapan hara dan air dari daun dapat diabaikan (Handayani, 2002). Hal ini berarti untuk mendapatkan pertumbuhan yang baik, tanaman harus mempunyai akar dan sistem perakaran yang cukup luas untuk dapat memperoleh hara dan air sesuai dengan kebutuhan tanaman, dengan demikian akan berdampak pula pada perbedaan berat segar akar tanaman.

\subsection{Berat Kering Akar Rumput Gajah}

Hasil sidik ragam menunjukkan bahwa tidak terjadi interaksi antara pemberian jenis teh kompos dan dosis biochar terhadap pengamatan berat kering akar. Perlakuan kontro nyata memiliki bobot kering akar (12,70 g) paling berat dibanding perlakuan lainnya. Hasil pengamatan berat kering akar rumput gajah di tampilkan pada Tabel 7 .

Tabel 7. Berat Kering Akar Rumput Gajah yang Memperoleh Jenis Teh Kompos dan Level Biochar yang Berbeda(g)

\begin{tabular}{lcccc}
\hline \multirow{2}{*}{ Jenis Teh Kompos } & \multicolumn{3}{c}{ Dosis Biochar $(\mathrm{g})$} & \multirow{2}{*}{ Rerata } \\
\cline { 2 - 5 } & Kontrol & 250 & 500 & $6,72^{\mathrm{b}}$ \\
\hline Kontrol & 11,66 & 5,54 & 2,96 & $11,88^{\mathrm{a}}$ \\
Feses Ayam & 13,97 & 10,17 & 11,5 & $11,30^{\mathrm{a}}$ \\
Feses Kambing & 16,92 & 9,25 & 7,73 & $6,98^{\mathrm{b}}$ \\
Feses Sapi & 8,25 & 7,9 & 4,78 & $(-)$ \\
\hline \multicolumn{1}{c}{ Rerata } & $12,70^{\mathrm{a}}$ & $8,22^{\mathrm{b}}$ & $6,74^{\mathrm{b}}$ & $(\mathrm{y})$
\end{tabular}

Keterangan: Angka pada kolom dan baris diikuti huruf sama, menunjukkan tidak berbeda pada tingkat nyata ( $\alpha$ ) $5 \%$, uji DMRT. (-): Tidak terjadi interaksi antar faktor

Pada Tabel 7. menunjukkan bahwa berat kering akar stek rumput gajah yang mendapat perlakuan kontrol memberikan berat kering akar yang paling berat $(12,70 \mathrm{~g})$. Ha ini diduga karena faktor predisposisi lingkungan dimana pada media tumbuh tidak mengandung nutrien (unsur hara) yang cukup sebagaimana perlakuan lainnya, sehingga tanaman mengalami abnormalitas pertumbuhan.

\section{Simpulan}

Disimpulkan bahwa perlakuan aplikasi teh kompos berbahan dasar feses ayam dan biochar $500 \mathrm{~g} /$ pot mampu meningkatkan produktivitas tanaman dilihat dari tinggi tanaman, jumlah helai daun, diameter batang, berat segar daun, dan berat kering daun rumput gajah.

\section{Pustaka}

Gani, A. 2010. Potensi Arang Hayati Biochar Sebagai Komponen Teqnologi Perbaikan Produktifitas Lahan Pertanian. Peneliti Balai Besar Penelitian Tanaman Padi, Sukamandi.

Glasser, B., J Lehman and W. Zech. 2002. Ameliorating physical and chemical propertyes of higly weatheret soil in the tropic with chorcoal- A review. Biology and fertility of siols. 35: 219-230.

Handayani, I. P. 2002. Laporan Penelitian Pendayagunaan Vegetasi Invasi Dalam Proses Agradasi Tanah Untuk Percepatan Restorasi Lahan Kritis. Lembaga Penelitian Universitas Bengkulu, Bengkulu.

Lehmann J. and S. Joseph. 2009. Biochar for environmental management: an introduction. science and technology.In: Lehmann and Joseph (Eds.). First published by Earthscan in the UK and USA in 2009.

Lehmann J. 2007. Bioenergy in the black. Frontiers in Ecology and then Environment 5: 38 $-387$.

Lehmann J., J.P. da Silva Jr., C. Steiner, T. Nehls, W. Zech, and B. Glaser. 2003. Nutrient availability and leaching in an archaeological Anthrosol and a Ferralsol of the Central Amazon basin: fertilizer, manure and charcoal amendments. Plant and Soil 249:343 357.

Lehmann J. and M. Rondon. 2006. Biochar soil management on highly weathered soils in the humid tropics. p: 51 7-530 In Biological Approaches to Sustainable Soil Systems (Norman Uphoff et al Eds.). Taylor \& Francis Group PO Box 409267 Atlanta, GA 30384-9267.

Litterick, A.M., Harrier L.,Wallace P., Watson C.A.,Wood M. 2004. The roleofun composted materials, composts, manure, and compost extractsin reducing pest and disease incidence and severity insustainable temperate agricultural and horticultural cropproduction - A review. Critical Re- viewsin Plant Science.

Nasir. 2007. Pengaruh Penggunaan Pupuk Bokasi Pada Pertumbuhan dan Produksi Padi Palawija dan Sayuran.

Niinemets, V. 2007. Photosyntesis and resource distriburion trough plant canopies. Plant, cell and Environment (2007) 30, 1052-1071

Rukmana, R. 2005. Rumput unggul hijauan makanan ternak. Penerbit Kanisius. Yogyakarta

Ryoo J.W. 2014. Effect of the Different Material Combinations of Compost and Steeping Solution on Characteristics of Compost Tea and Growth of Ginseng (Panax ginseng C. A. Meyer). Korean J. Int. Agric. 26: 141-147.

Steiner C, Teixera W., Lehman J., Nehls T., de Mecedo J., Blum W., Zech W., 2007. Long term effects of manure charcoal and mineral fertilization on crop production and fertility on a higly weathered central Amazonian unpland soil. 291:275-290.

Suyirman. 2003. Agrostologi. Universitas Andalas. 